\title{
Inhibitory Effect of Carbofuran Furadan 3G on the Cocoon Production and Viability in Pheretima javanica Gates
}

\author{
Erwin Nofyan ${ }^{1}$, Syafrina Lamin ${ }^{1}$, Innocenthya Tygra Patriot ${ }^{1}$, \\ Mohammad Kanedi ${ }^{2}$ \\ ${ }^{I}$ Department of Biology, Faculty of Mathematic and Sciences, Sriwijaya University, Palembang, Indonesia \\ ${ }^{2}$ Department of Biology, Faculty of Mathematic and Sciences, University of Lampung, Bandar Lampung, \\ Indonesia
}

\begin{abstract}
Though carbofuran has known to possess adverse effects in soil organisms including earthworms, little is known about the effects of carbofuran, either dirrectly or indirrectly, on the earthworm Pheretima javanica. This study aimed to investigate the effect of carbofuran at sublethal doses on the cocoons production and viability of Pheretima javanica worms. Six groups of earthworms, each consisted of four worms, were reared in plastic pots and fed on cow manure mixed with carbofuran as much as $0 \mathrm{mg}$ (for control), $0.1 \mathrm{mg}$, $0.2 \mathrm{mg}$, $0.3 \mathrm{mg}, 0.4 \mathrm{mg}$ and $0.5 \mathrm{mg}$ repectively. Cocoons produced were hand sorted every two weeks for three months and presented as the number of cocoons per individual per moth. Cocoon viability was determined by observing the hatchling emerged from the cocoons incubated in Petri dish and expressed as percentage of viability. The results showed both cocoons production and cocoon viablity of the worms decreased significantly by the increasing concentration of the pesticide given $(\alpha=0.05)$. Thus, it can be conclusively suggested that carbofuran (Furadan 3G) highly harmful to earthworm Pheretima javanica, even at low concentrations adversely affect growth and reproduction of the worms.
\end{abstract}

Key words: carbofuran, Furadan G3, carbamate pesticide, earthworm, Pheretima javanica

\section{Introduction}

Although many countries have banned the spread and use of carbofuran, here in Indonesia, this carbamate pesticide under the trade mark of Furadan 3G, Curater 3G or Indofuran 3G is still intensively used in agriculture and plantation including rice, citrus, cotton, clove, pepper, potato, sugarcane, and tobacco. Because of its widespread use for many decades the residues of these chemicals are potential to contaminate the terrestrial and aquatic environments. The evidence of high carbofuran residues in soil and water due to intensive use of carbamate pesticides and its impact on biological system have been indicated by both field and laboratory studies from many parts of he world such as Kenya [1], India [2, 3], and Bangladesh [4]. In Malaysia, carbofuran even detected in river, sea and ground water in pollution-free areas [5]. From Czech Republic it was reported that the number of intoxicated animals did not decline even though carbofuran use has banned for two years [6].

Research findings mentioned above are the depiction of potential adverse ecological effects of pesticide uses on biological organization that may lead to loss in production, changes in growth, development and/or behavior, changes in system processes (such as nutrient cycling), and losses of valuable species [7]. One of valuable organism group possessing great role and services for both ecological and farming systems is earthworms. Earthworm, due to capable of producing cellulase enzyme in its gut make this Oligochaeta worm contributes to the nutrient cycling in terrestrial ecosystem [8] and affects physicochemical properties of soil [9]. In a review article on the benefits of earthworms for cropping system, Bertrand et al. [10] summarizing that earthwoms improve soil structural stability and soil porosity and reduce runoff, modify soil organic matter (SOM) and nutrient cycling, allegedly contribute to crop production, enhance organic amendments. However, due to feeding at soil surface earthworm most exposed to pesticides and other agrochemicals.

Considering the important role of earthworms in nutrient cycling process in terrestrial ecosystem on the one hand, the high agrochemical threats on the other, studies on the impact of agrochemicals on the biological aspects of earthworms are crucial. Different types of agrochemicals such as cyfluthrin, carbaryl, chlorpyrifos, fipronil, imidacloprid, pendimethalin, pretilachlor, cypermethrin, pentachlorophenol, parathion, carbendazim, paraquat, fentin, benomyl, carbaryl, phenmedipham, copper oxychloride, and dieldrin have been tested against earthworms using various biological parameters including reproductive. Though various species of earthworms have been used as test animals including Lumbricus terrestris, Aporrectodea giardi, Perionyx excavatus, Eisenia fetida, Enchytraeus luxuriosus, Enchytraeus albidus, Pheretima posthuma, and Pheretima (Metaphire) hilgendorfi, but none of the studies involved Pheretima javanica as the subject [11]. This study is intended to know the effect of carbofuran (Furadan 3G) at sublethal dose, according to Eisler [12], on the cocoons production and cocoons viability of Pheretima javanica worms. 


\section{Earthworm collection}

\section{Materials And Methods}

Samples of Peheretima javanica were collected from suburb area of Palembang and Inderalaya, district of Ogan Ilir, the province of South Sumatra, Indonesia. The worms obtained by digging the ground at the depth of 10-15 cm and then hand-sorted. Soil matter free from litter and worm packed and taken to the laboratory to serve as a medium for rearing the worms in the experiment. Worms for test animal stocks were kept in a plastic tray sized of $20 \times 30 \times 10 \mathrm{~cm}$ at room temperature with the soil water content range $30-40 \%$ and fed on cow manure ad libitum.

\section{The Pesticide}

The pesticide carbofuran (2,3-dihydro-2, 2-dimethylbenzofuran-7-yl methylcarbamate) used in the experiment was the Furadan $3 \mathrm{G}$, a granular formulation that contains $3 \%$ pure carbofuran, a product from PT. Bina Guna Kimia, Indonesia, Registration No. RI. 010101197416.

\section{Experimental design}

There were six levels of treatments applied in this study based on the concentration of carbofuran namely: $0 \%$ (as the control), $0.1 \%, 0.2 \%, 0.3 \%, 0.4 \%$ and $0.5 \%$. Each level of concentration was made by mixing $100 \mathrm{mg}$ of cow manure (the worm foods) with the carbofuran granules as much as $0 \mathrm{mg}$ (for control), $0.1 \mathrm{mg}, 0.2 \mathrm{mg}, 0.3 \mathrm{mg}, 0.4 \mathrm{mg}$ and $0.5 \mathrm{mg}$ respectively. By using a completely randomized design, each treatment involved four replications.

\section{Cocoon Production}

Plastic pots with the diameter of $20 \mathrm{~cm}$ and height of $15 \mathrm{~cm}$ were used for treating the worms in this study. Soil $(1000 \mathrm{~g})$ taken from the original biotope were put into the pot and served as the rearing medium for the worms. The water content in the soil medium on each pot was maintained in the range of $30-40 \%$. Into each pot was placed four adult earthworms (two pairs) that fed with cow dung $(250 \mathrm{mg})$ which has been mixed with carbofuran in accordance with the concentration planned. Every two, for total 3 months of rearing, weeks the cocoons deposited were hand sorted. Every two weeks, for a total duration of three months, the deposited cocoons were hand sorted. The cocoon production rate was expressed as the average of cocoon per worm per month.

\section{Cocoon Viability}

All cocoons obtained from each pot of cocoon production experiment were incubated on filter paper spread over water soaked cotton inside a petri-dish. Cocoons were observed in daily basis to record any hatchlings emerged. Hatchability of cocoons (cocoon viability) were presented as percentage assessed using equation belows.

$$
\text { Cocoon viabilty }=\frac{\text { number of juvenile }}{\text { number of cocoons }} \times 100 \%
$$

\section{Statistical analysis}

The data of cocoons production and cocoon viabitiy were analyzed using one-way ANOVA followed by Duncan Multiple Range Test (DMRT) as the post hoc test at the $95 \%$ confidence level.

\section{Results And Discussion}

This study findings, as can be seen in Table 1, clearly indicated that pesticide carbofuran (Furadan 3G) significantly inhibit cocoons production and cocoon viability in Pheretima javanica worms. Both the cocoons production rate and cocoon viability are significantly decreased by the increasing concentration of carbofuran given $(\alpha=0.05)$. These data seem to strengthen what Govindarajan [13] has mentioned that majority of carbamate such as aminocarb, methiocarb, oxamyl, promecarb, aldicarb, bufencarb, carbaryl, carbofuran, methomyl, propoxur and thiofanox are toxic to earthworms and strongly affect population of earthworms.

Table 1 Cocoons production and viability of Pheretima javanica Gates fed on cow dung contaminated with pesticide carbofuran Furadan 3G

\begin{tabular}{|c|c|c|}
\hline $\begin{array}{c}\text { Concentration of Carbofuran } \\
(\%)\end{array}$ & $\begin{array}{c}\text { Cocoons Production } \\
\text { (cocoons/worm/month) }\end{array}$ & $\begin{array}{c}\text { Cocoons viability } \\
(\%)\end{array}$ \\
\hline 0 & $7.75 \pm 1.25^{\mathrm{a}}$ & $78.75 \pm 1.25^{\mathrm{a}}$ \\
\hline 0.1 & $4.33 \pm 1.02^{\mathrm{b}}$ & $50.20 \pm 3.02^{\mathrm{b}}$ \\
\hline 0.2 & $3.20 \pm 0.80^{\mathrm{c}}$ & $20.20 \pm 2.80^{\mathrm{c}}$ \\
\hline 0.3 & $2.93 \pm 0.24^{\mathrm{d}}$ & $15.93 \pm 3.24^{\mathrm{d}}$ \\
\hline 0.4 & $1.00 \pm 0.15^{\mathrm{e}}$ & $5.75 \pm 1.02^{\mathrm{f}}$ \\
\hline 0.5 & $0.25 \pm 0.02^{\mathrm{f}}$ & $5.15^{\mathrm{e}}$ \\
\hline $\begin{array}{l}\text { Data are presented as Mean } \pm \text { SD. Values in the same column followed by the same superscript are } \\
\text { not different at } \alpha=0.05\end{array}$ & \\
\hline
\end{tabular}


Based on a study to investigate the effects of butachlor herbicide on earthworm Eisenia fetida, Muthukaruppan and Gunasekaran [14] found the earthworm biomass and cocoons production were decreased with increasing herbicide concentration. These data lead the authors hypothesized that butachlor increased the worm demand for energy needed for the regulation and detoxification of herbicide. The decrease in worms biomass might also be related to the low food consumption rate. As mentioned food consumption rate of earthworm is affected by quality of food given such as taste, smell, chemical composition that influenced palatability [15]. In this experiment, the cow manure (food source) was mixed with carbofuran. The presence of the pesticide seemed to change food palatability of cow manure. In addition the test animals are kept in a plastic pot with that make the worms have no choice for food to consume other than the carbofuran-polluted manure. In natural soil habitat, in fact, the worm does not feed on soil indiscriminately but is able to select an organic matter-enriched diet from the medium [16]. In Eisenia fetida when food quality changed, not only the growth rate of the worms affected, but cocoons production and hatchlings produced significatly decrease as well [17].

Other factors most likely affecting directly cocoon production in earthworms exposed to the pesticides were the histological and cellular effects of the carbofuran. As has been reported, agrochemical Butachlor ( a herbicide) found to cause glandular cell enlargement at all the exposed concentrations, which might massively affect food intake and which in turn may indirectly inhibit the earthworm reproductive capacity [18]. Cellular impairment that lead to growth and reproductive inhibition in erathworm due to chemical exposed has been found in Eisenia andrei upon treated with cadmium [19]. Another degenerative effect of insecticide (Azodrin ) on body tissue of earthworms was reported by Leena [20] which found that spermatic follicles significantly degenerated due to clumping, vacuolization and necrosis.

Lastly, as already known for decades, the carbofuran-induced fatalities are due to these compounds developed two type of lesions in worms namely a multi segment swelling which often ulcerated and a discrete nodular mass protruding from the surface of the worm [21]. Besides, as has been indicated, carbamate pesticide along with organophosphates, strongly inhibits acetylcholinesterase (AChE) activity in a number of invertebrate species [22]. In earthworm Eisenia foetida this enzyme responsible for stability of lysosomal membrane of coelomocytes [23] and activity of muscle cells in the clitellum [24]. When the muscle cells of clitellum adversely impaired, its major role in cocoons production will ceased and consequently causes low reproductive capacity.

\section{Conclusion}

Although there are many aspects that still need to be studied in earnest, mainly with regards to the physiological mechanisms of carbofuran in affecting reproductive system of the worms, it can be conclusively suggested that carbofuran (Furadan 3G) highly harmful to earthworms growth and reproduction, even at low concentrations below $0.5 \%$.

\section{References}

[1] Otieno P.O., Lalah J.O., Virani M., Jondiko I.O. and Schramm K.W. 2010. Carbofuran and its Toxic Metabolites Provide Forensic Evidence for Furadan Exposure in Vultures (Gyps africanus) in Kenya. Bull Environ Contam Toxicol., April 2010. DOI 10.1007/s00128-010-9956-5

[2] Bhagabati K.S. and Sarma H. Differential effects of pesticides on soil microflora in cultivated soil of Indian rice field agroecosystems. Journal of Applied and Natural Science, 2011; 3 (2): 277-279.

[3] Selvaraj S., Basavaraj B. and Hebsur N.S. Pesticides Use and Their Residues in Soil, Grains and Water of Paddy Ecosystem - A Review. Agri. Reviews, 2014; 35(1): 50-56.

[4] Chowdhury M.A.Z., Banik S., Uddin B., Moniruzzaman M., Karim N. and Gan S.H. Organophosphorus and Carbamate Pesticide Residues Detected in Water Samples Collected from Paddy and Vegetable Fields of the Savar and Dhamrai Upazilas in Bangladesh. Int. J. Environ. Res. Public Health, 2012; 9: 3318-3329; doi:10.3390/ijerph9093318

[5] Farahani G.H.N., Zakaria Z., Kuntom A. and Ismail B.S. Persistence of Carbofuran in Malaysian Waters American-Eurasian J. Agric. \& Environ. Sci., 12 (5): 616-623, 2012

[6] Novotný L., Misík J., Honzlová A., Ondráček P., Kuča K., Vávra O., Rachač V. and Chloupek P. Incidental poisoning of animals by carbamates in the Czech Republic. J Appl Biomed., 2011; 9: 157-161.

[7] Zacharia J.T. (2011). Ecological Effects of Pesticides, Pesticides in the Modern World - Risks and Benefits, Dr. Margarita Stoytcheva (Ed.), ISBN: 978-953-307-458-0, InTech, Available from: http://www.intechopen.com/books/pesticides-in-the-modernworld-risks-and-benefits/ecological-effects-ofpesticides

[8] Nozaki M., Miura C., Tozawa Y. and Miura T. 2008. The Role of the Earthworm, Pheretima (Metaphire) hilgendorfi, in Terrestrial Ecosystem Nutrient Cycling. In: Y. Murakami, K. Nakayama, S.-I. Kitamura, H. Iwata and S. Tanabe (Eds). Interdisciplinary Studies on Environmental Chemistry-Biological Responses to Chemical Pollutants, pp. 275-279

[9] Kale R.D. and Karmegam N. The Role of Earthworms in Tropics with Emphasis on Indian Ecosystems Applied and Environmental Soil Science Volume 2010 (2010), Article ID 414356, 16 pages

[10] Bertrand M., Barot S., Blouin M., Whalen J., de Oliveira T. and Roger-Estrade J. Earthworm services for cropping systems. A review. Agron. Sustain. Dev. (2015) 35:553-567 DOI 10.1007/s13593-014-0269-7

[11] Yasmin S. and D'Souza D. Effects of Pesticides on the Growth and Reproduction of Earthworm: A Review. Applied and Environmental Soil Science Volume 2010, Article ID 678360, 9 pages doi:10.1155/2010/678360

[12] Eisler, R. 1985. Carbofuran hazards to fish, wildlife, and invertebrates: a synoptic review. U.S. Fish and Wildlife Service Biological Report 85 (1.3). 36 pp. 
[13] Govindarajan B. A Review of Studies Performed to Assess Pesticide Pollution by Earthworm's Growth. International Journal of Pharmacy Review \& Research. 2014; 4(3): 143-146.

[14] Muthukaruppan G. and Gunasekaran P. Effect of Butachlor Herbicide on Earthworm Eisenia fetida-Its Histological Perspicuity. Applied and Environmental Soil Science. Volume 2010 (2010), Article ID 850758, 4 pages. http://dx.doi.org/10.1155/2010/850758

[15] Erdward C.A. and Lofty J.R. 1977. Biology of Earthworm. Chapman and Hall, New York. p: 333

[16] Jager T., Fleuren R.H.L.J., Roelofs W. and de Groot A.C. Feeding activity of the earthworm Eisenia andrei in artificial soil. Soil Biology \& Biochemistry, 2003; 35: 313-322

[17] Siddique J., Khan A.A., Hussain I. and Akhter S. Growth and Reproduction of Earthworm (Eisenia fetida) in Different Organic Media. Pakistan J. Zool., 2005; 37(3): 211-214

[18] Muthukaruppan, G., Janardhanan, S. and Vijayalakshmi, G. Sublethal Toxicity of the Herbicide Butachlor on the Earthworm Perionyx sansibaricus and its Histological Changes (5 pp). J Soils Sediments, 2005; 5: 82. doi:10.1065/jss2004.09.111

[19] Takacs V., Molnar L., Klimek B., Galuszka A., Morgan A.J. and Plytycz B. Exposure of Eisenia andrei (Oligochaeta; Lumbricidea) to Cadmium Polluted Soil Inhibits Earthworm Maturation and Reproduction but not Restoration of Experimentally Depleted Coelomocytes or Regeneration of Amputated Segments. Folia Biologica (Kraków), 2016; 64 (4): 275-284

[20] Leena L. Effect of Azodrin on the Testes of the Earthworm Eudichogaster kinneari (Stephenson): A Histological and Histochemical Profile. Int. Res. J. Biological Sci. 2013; 2(9): 54-58.

[21] Sileo L. and Gilman A. Carbofuran-induced muscle necrosis in the earthworm. Journal of Invertebrate Pathology, 1974; 25(1): 145148

[22] Booth L.H., Heppelthwaite V. and Eason C.T. Cholinesterase and Glutathione S-Transferase in The Earthworm Apporectodea Caliginosa as Biomarkers of Organophosphate Exposure. Proc. 51st N.Z. Plant Protection Conf. 1998: 138-142

[23] Gambi N., Pasteris A. and Fabbri E. Acetylcholinesterase activity in the earthworm Eisenia andrei at different conditions of carbaryl exposure. Comp Biochem Physiol C Toxicol Pharmacol. 2007;145(4):678-85.

[24] Bansiwal K. and Rai N. Ultra Structural Changes in Clitellum Region of Eisenia Foetida After Treatment with Malathion. Bioscan., 2010; 5(2): 207-210 